\title{
Reciprocity and solidarity in intergenerational relationships: Spain, France and Norway in comparative perspective*
}

\author{
Constanza Tobío Soler \\ Universidad Carlos III de Madrid. Departamento de Ciencia Política y Sociología \\ ctobio@polsoc.uc3m.es
}

Recibido: 16-08-2010

Aceptado: 18-01-2012

\begin{abstract}
Contrary to the idea that kinship support declines with modernisation, it may be a key resource in the transition from a traditional male breadwinner family to a dual-earner model, either as a substitute of working mothers or as a complement in addition to other resources. Grandparents as carers of their grandchildren go beyond intergenerational reciprocity by giving more than they can expect to receive from other generations. This article presents the case of Spain in comparative perspective with France and Norway, and discusses to what extent grandmothers assuming the traditional mothering role, with the help of grandfathers, can be considered a model for the future or rather a provisional solution for a transitional period.
\end{abstract}

Keywords: kinship; family networks; gender; care; grandparents.

Resumen. Reciprocidad y solidaridad en las relaciones intergeneracionales: España, Francia y Noruega en perspectiva comparada

Frente a la idea generalizada de que la ayuda familiar disminuye con el proceso de modernización, puede, por el contrario, ser un elemento clave en la transición de la familia tradicional, basada en la división de roles de género, a la familia de dos ocupados, bien en sustitución de la madre trabajadora o como complemento de otros recursos. Las abuelas y los abuelos que cuidan de sus nietos van más allá de la reciprocidad intergeneracional al dar más de lo que pueden esperar recibir de las otras generaciones. El artículo presenta el caso de España en comparación con Francia y Noruega, planteando hasta qué punto las abuelas que asumen, con la ayuda de sus cónyuges, el rol maternal tradicional pueden considerarse un modelo de futuro o una solución provisional para un periodo de transición.

Palabras clave: parentesco; redes familiares; género; cuidado; abuelos.

* This article explores theoretical aspects of the relationship between kinship support, social policy and family models. It draws its empirical data from previous comparative research on Spain, Italy, Norway and France (Leira et al., 2005; Fernández Cordón and Tobío, 2007; Tobío, 2008) 


\author{
Summary \\ Introduction Three case studies \\ Reciprocity and solidarity Grandparents, a substitute \\ Kinship support as a substitute \\ or complementary resource for childcare? \\ or a complement \\ Bibliographic references
}

\title{
Introduction
}

Intergenerational relationships are mainly about reciprocity. In ancient times what each generation received and gave was simple: being cared for when small and taking care of their own children until they could rely on themselves. Myths in different contexts and cultures ${ }^{1}$ tell us about the elderly being abandoned or even killed when they became a burden for their able adult children (Simmons, [1945] 1970). Progressively, caring for those who have been active throughout their life but will not be any longer becomes both possible, as there is an economic surplus to maintain them; and imperative, as a new moral sense imposes care of the elderly as a duty. Reciprocity between generations becomes more complex as care for old people comes in, and this happens more often due to increasing life expectancy. Each generation now gives twice. As adults, they usually care for their small children first and then look after their elderly parents. And each person receives twice, once from the preceding generation (children are cared for by parents) and once from the succeeding one (the elderly are cared for by their children). A three generation chain is thus weaved, assuring survival through the different stages of life. According to the norm of reciprocity, burden and support, as well as rights and obligations, are balanced, even if what is actually given or received might not be exactly equivalent.

Yet sometimes a certain generation seems to give clearly more than they can expect to receive, thus going beyond reciprocity in what has been described as solidarity (Ostner, 2004) or altruism (Silverstein et al., 2002). This was the case for the first generation of elderly who were taken care of by their adult children when they could not make a living, even if that was not what they did when their parents could not survive by themselves any more. This is also the case in collective or individual tragedies such as war, death or illness, when parents cannot look after their small children and grandparents assume that role.

This article focuses on another case of solidarity: that of Spanish grandparents who are currently the main resource for the care of small children when their mothers work, which is now the norm. Grandparents are often the main carers of their grandchildren, and sometimes even full-time carers, but they sel-

1. The film "The Ballad of Narayana" by Shoei Inamura shows how in rural areas of Japan the archaic tradition of taking the elderly to a far away mountain and leaving them to die persisted until the beginning of modernisation. 
dom share the same household. They provide their help not in special or exceptional situations but in normal cases of children living with both parents. The key carer is the maternal grandmother, but maternal grandfathers are becoming increasingly involved as well. The question is, how can the intensive support provided by Spanish grandparents be conceptualised? From a sociological perspective, there are two sets of possible answers. One relates to specific characteristics of the family and the welfare regime in Southern European countries. There is a wide debate on the "familism" of the Mediterranean model and to what extent it can be considered a specific welfare type in addition to the social democratic, liberal and conservative welfare models (Esping-Andersen, 1999; Moreno, 2000; Anttonen and Sipilä, 1996; Leitner, 2003; Castles and Obinger, 2008; Ranci, 2010). In this sense, grandparents' help is part of a welfare model based on the family as the main resource. Another way to look at this issue has to do with social change. From this point of view, kinship support can be understood as an exceptional resource in a transitional period from the Parsonian family based on the division of roles between mother and father as carer and provider, to a dual-earner family where both parents engage in paid work. When the nuclear family is not enough and social policies are not yet in place, support from the extended family may be the only available resource for working mothers.

This raises other questions as, for example, if kinship support has to do with models of the past based on strong family relationships, or rather points to a new emerging model that has yet to be fully developed. How does grandparents' help modify intergenerational reciprocity? Is solidarity a new form of relationship among generations? Has a similar phenomenon been observed in other countries?

The first part of the paper deals with conceptual aspects. Reciprocity is a specific kind of exchange in which stability, time and social bonds are key aspects. When the balance between donors and receivers is altered and some clearly give more than others and more than they can expect to receive in the future, the notion of solidarity appears. This is a complex concept that has been used in sociology since Emile Durkheim and Ferdinand Tönnies in different ways, but all of which are related to social integration.

The article then goes on to discuss how kinship support can complement or substitute other forms of care. Kinship support can be just one more resource among others, which together compose a patchwork care strategy ${ }^{2}$ or it can substitute a main resource. This raises the issue of who is being substituted, and thus considered to hold the responsibility of care. It is not a purely analytical question, but also normative: who used to be in charge and is not any more (e.g. now employed mothers) or who should assume the responsibility of care and to what extent (family or state). Grandparents' help as a complementary

2. Lauro Balbo (1987) put forward the successful "quilt metaphor" to refer to the ways women, and particularly working mothers, use to put together, combine and add up a wide variety of resources to meet the demands of employment, care and family responsibilities in everyday life. 
or substitute resource is part of a broader social policy debate regarding the effect of state intervention on the family. A new version of this debate is the "crowding out" hypothesis according to which generous welfare states crowd out support provided by the family to its dependent members, thus weakening social ties. An alternative hypothesis, "crowding in", posits that active policies focusing on care do not replace, but rather reinforce support provided by the family.

The third and main part of the article presents three empirical case studies with a comparative purpose. It has often been said that Spain is a good laboratory for social research as the pace of social change has been very rapid. Only thirty years ago it was a very traditional society with high fertility, low female employment, and no divorce or abortion laws. Today, a majority of mothers of small children are in the labour market, almost one-third of births are out of wedlock, homosexual marriages are legal, and half of the judges or members of the government are women. During the eighties, a decade affected by deep economic crisis, long delayed social policies were at last adopted to provide universal access to education, health services and old age pensions. Childcare was not a priority in a context of limited resources, in spite of the rapid involvement of women in paid work. The transition to a dual-earner family model was based, and still is to a considerable extent, on support from family networks, particularly grandparents.

France is a very different case as social policies targeted at the family have been very generous for a quite a long time. For more than a century, female activity in France has been higher than in most European countries, with the exception of Northern Europe, and fertility is now also high in the country. There is a wide variety of public resources available to help families raise their children at home or in collective crèches, by their parents or by professional carers. In spite of that, a majority of grandparents do play a role as carers on a regular basis to fill in gaps or to create a bond with their grandchildren beyond pure entertainment. Yet such care is usually only a limited and partial form of support in addition to other care resources. The French case is therefore a good example of the "complementary thesis".

The ideology of the nuclear family as being independent and standing on its own is strong in Norway as well as in other Nordic countries. Support for childcare, or other care needs, comes mainly from the state through policies targeted at individuals. Grandparents or other kin are not considered to be resources for care; it is for other persons or institutions to provide. But going back in time to the 1960s when mothers were rapidly entering the labour market in Norway (as Spanish mothers would do thirty years later), informal support for care, including grandparents, did play a role as social policies were scarce and unable to meet the growing demand for care. Members of the extended family, neighbours and friends substituted mothers who were no longer full-time carers. Norway was then an example of the "substitution thesis". By the 1980s, however, the state became involved and public care services were made available to all children. 
The last part of the article examines intensive kinship support for childcare in Southern Europe under the complementary hypothesis (France) and the substitution hypothesis (Norway). It discusses to what extent these two cases help to understand Spanish grandparents. Do they represent a possible model for the future or will family networks continue to be the main care providers?

\section{Reciprocity and solidarity}

The process of modernisation is strongly related to an increase and diversification of exchange. This is a core issue in nineteenth-century social sciences, particularly in economics and sociology. For economists, from Adam Smith to Ricardo or Marx, the main concern is about the value of things exchanged; taking for granted that the rules are those of the market. What is given and what is received must be of equal value and must also be simultaneous. The exchange relationship is perfectly symmetrical. The conditions of the deal are explicit, and usually subject to a formal legal framework which regulates the rights and obligations of both parties. Those who are involved need not be related to each other beyond the market relationship. Each transaction is independent; it starts and finishes at the moment when something is given and received, bought or sold. The transaction can be repeated, but as a new deal. The key issue is to ensure that what is exchanged is really of equal value. In the barter system things are exchanged directly, for example a cow for a horse, or a table for a bed, so the value calculation is approximate. When money comes in, everything can be easily exchanged and it is possible to fine tune the value of things.

The sociological approach is different. Its main concern is social integration. Exchange is conceived in terms of the social division of work and interdependence among individuals and social groups. As industrialisation develops, the scale of cooperation increases and becomes unavoidable. Even if the explicit aim of exchange is sheer interest, mutual dependence produces a new kind of social cohesion in modern societies.

The main sociological concept related to exchange is reciprocity. Reciprocity does not require simultaneity between giving and receiving, nor exact equivalence. Things, objects, services or symbols are exchanged according to a non-monetary logic. There is, though, an expectation-not a formal right- to receive something of similar value in the future (Gouldner, 1960). However, it does not necessarily have to be the same kind of thing as that which was formerly received, and the exact moment of giving back does not need to be defined. Between what is given and what is received there is a short or long period of time, and that delay is precisely the key issue about reciprocity because the difference between these two moments creates a social bond. The most clear example of reciprocity are gifts (Mauss, 2000 [1950]). Often, the actual content of the gift is the least important as the gift is instead a symbol of relationships, a way of renovating and acknowledging its existence. To give may be an obligation, but so is receiving and giving back. According to Mauss, 
not accepting a gift was a declaration of war in some cultures. Giving a gift may have nothing to do with the actual needs of the individual who receives it. In fact, giving may be a way of accumulating the right to receive in the future, or even an exhibition of power and wealth. Each of the three moments of reciprocal exchange - giving, receiving and giving back-represents a different social position. As time goes on, individuals shift from one to another, thus creating complex chains of mutual recognition and obligation which are continuously reproduced. To give back means giving, and the cycle is thus renovated.

The reciprocal system implies delayed exchange over time which produces and reinforces social relationships. Reciprocity requires a wide time horizon, as well as a stable framework for social interaction. Individuals or groups involved in reciprocity have to keep in touch to maintain interaction (Ostner, 2004). It also requires trust, as there is no formal obligation to give back or nothing that specifies exactly what has to be given. Trust and interaction are closely related, thus explaining rituals that keep reciprocity alive. Family celebrations, gatherings with peers or similar social events remind participants of their relative positions in social networks and induce them to interaction, thus building trust.

In short, reciprocity is a complex and subtle phenomenon compared to market exchange. Where the latter is formal, explicit and precise, the former is informal, implicit and approximate. Reciprocity is context sensitive and, at the same time, extremely flexible. However, people usually know exactly what they owe in each situation, and how and when to give back. Reciprocity is very much about implicit knowledge shared among participants in social interaction (Garfinkel, 1984).

The concept of reciprocity is a useful analytical tool to describe intergenerational relationships. Among parents, children and grandchildren, positions are asymmetrical in terms of who needs what kind of support, but they change along the life course. What is given can be considered a sort of private social security system with deposits to be withdrawn in times of need (Antonucci and Jackson, 1990). Reciprocity among family generations implies a commitment to care for small children and for elderly parents, as well as the expectation to be cared for in old age. Care and support from parents are taken for granted by children, but as they grow up they assume a reciprocal obligation towards them. Caregiving does not take the form of a contract, as it is not formal, or explicit, nor are the parties symmetrical. It does not even include all family members in the same way. It has been, and still is to a considerable extent, up to the women of the family to provide care according to a hierarchy of relatives. Actual caregiving is subject to a process of negotiation in which the specific needs of all parties involved are taken into account in a framework of norms, affection and reciprocity (Finch and Mason, 1993).

Solidarity is a related concept that has been understood in different ways by social scientists. According to Emile Durkheim's theory (1956 [1893]) on social cohesion, solidarity is what keeps societies together. It changes along the process of modernisation. In the past, integration was based on commonly 
shared values and similarities in behaviour and activities. This kind of social glue is called "mechanic solidarity" as opposed to "organic solidarity", which is based on the opposite characteristics. The increasing social division of work as a result of industrialisation creates a different kind of integration among individuals and social groups based precisely on functional diversity. Social integration is no longer the result of similarities between what people do, but rather the different functions they perform makes them mutually dependent in all aspects of life.

Some nineteenth-century economists and political scientists such as Charles Gide (1893) or Léon Bourgeois (1998 [1896]) were also interested in the notion of solidarity. Bourgeois developed a specific approach based on the idea of "social debt" and founded a social and political movement of considerable influence in France. The main argument is that all individuals from the moment of birth are in debt with those who preceded them and made their existence possible. Interdependence among the members of industrial societies, which is the basis of solidarity as understood by Durkheim, is enlarged in Bourgeois's theory to include former generations, as well as all other aspects of life, not just market exchange. Each generation receives from the preceding ones and has the responsibility of keeping and increasing such a legacy, and passing it on to those who come after. As Paugam (2007) points out, Bourgeois's approach opened a new path at the beginning of the twentieth century between individualistic and collectivist perspectives, which would take shape decades later in systems of mutual social provision. The key element in Bourgeois's theory is redistribution, that is, asymmetry between what is given and received, thus allowing some to receive more than others.

The concept of solidarity has experienced a semantic shift from its initial meaning of social integration to the actions taken to achieve it, with a focus on redistribution and thus towards the idea of asymmetric relationships in terms of giving and receiving. Terms like "public solidarity" or "solidarity actions" 3 are often used in the sense of giving to those who cannot afford what they need. Solidarity in this sense goes beyond reciprocity as it does not entail the obligation of giving back. In certain cases and at certain moments, an individual, a social group or a generation may give more than they can expect to receive or may receive more than they have given or will give in the future.

When viewed from a longitudinal perspective, intergenerational relationships follow the norm of reciprocity. At a cross-sectional micro-level, however, families are based on internal solidarity as their members are in different phases of their lives which require support (childhood, old age) or, on the contrary, make them available to give it (adults). In this sense, both concepts are related and, in a way, explained by each other. Yet even in long-term generational relationships, imbalance appears now and then. Going back in time, as mentioned before, the first elderly who were cared for when they became dependent

3. Other languages such as French or Spanish have adjectives (solidaire, solidario) to describe asymmetrical exchange with a redistributive purpose. 
received more as they had not done the same for their elderly parents. A closer example, though controversial, is that of generational accounting which looks for different cohorts at contributions paid to the state as opposed to benefits received, concluding that current rights for the elderly will have to be paid by the future generations with few chances to have a similar level of rights (Becker, 2000). Grandparents as carers are another case of intergenerational solidarity in that they give to other generations beyond reciprocity, that is, they give more than they can expect to receive.

Solidarity tends to be exceptional and is related to social change or exceptional situations. When an imbalance in generational exchange occurs, the norm of reciprocity soon seems to be recovered. If and how this will happen with Southern European grandparents is the main question that underlies this paper.

\section{Kinship support as a substitute or a complement}

The substitution thesis is based on the idea that as the state comes in, the family goes out. From a long-term historical perspective this is difficult to deny. One of the main features of the modernisation process is the loss of family functions in favour of other social and economic institutions, particularly the market and the state. Education and health have been assumed to be individual rights guaranteed by the state. In this sense, the state does substitute the family. Substitution, though, as understood by authors such as Popenoe (1996) means something different. According to a rational choice approach, people will not do what the state already does, so public intervention automatically diminishes what they do for other members of their family. Rationality is associated to money in terms of subsidies versus taxes, which explains individual actions. Social policies are regarded as socially dangerous because they undermine the motivation to support family members, thus reducing social cohesion.

A similar approach is the crowding out thesis (Künemund, 2008) framed in the unintended consequences of the social action perspective. In different cases, such as philanthropy, human resources or social policies, it is observed that intervention in response to a certain need or to promote a certain kind of behaviour has no effect as previous ways to deal with the specific issue addressed disappear. It may even prove to be counterproductive if crowded out resources outnumber those put in.

The substitution thesis has been contested on different grounds and alternative theories have been put forward. Knijn (2004) points out that the substitution thesis understands support for those who cannot make a living or take care of themselves in a very limited way, thus reducing them to cash payments, while care services provided by the state or the family are underrated. On the other hand, the family is conceptualised as restricted to the nuclear family, while the extended family, whose members do not cohabit, is a key resource for support as recent research throughout Europe and in many other countries 
shows (Attias-Donfut, 1995; Hansen, 2005; Bonvalet and Ogg, 2007; Véron et al., 2007). It has also been pointed out that the substitution thesis looks at exchange from a narrow economic and individualistic perspective, rather than a wider sociological one (Künemund, 2008). The underlying logic in giving support goes beyond what is actually given, and that there are different overlapping motives to give which relate to affection, responsibility, norms or reciprocity (Finch and Mason, 1993; Ungerson, 1990). It could also be added that the substitution approach does not take into account social change. The family today does not resemble very much the so-called modern family theorised by Parsons and Bales (2003 [1956]) more than fifty years ago.

The main change has to do with women, including mothers, entering paid work and becoming income providers for the family. The new family model based on two earners, or one in lone parent families, requires external support as mothers are no longer full-time carers.

Knijn (2004) has identified three main alternatives to the substitution approach: packaging, the complementary thesis and the transmission thesis. Inspired by research on survival strategies of poor families (Rainwater et al., 1986; Pahl, 1984), packaging looks at how families, and particularly women, combine different kinds of resources— public, private or informal — to respond to their needs. The main responsibility and the key strategic action lie in the family. Resources from the state may be greater or smaller and can be very important, but they do not substitute the family as the key agent for the wellbeing of individuals. The complementary thesis is closely related to packaging, but goes beyond it in terms of the effects of public policies. Collective support increases help provided by family members rather than opposing it, with both types of support being cumulative. It may even happen that those who receive ample public or private support will receive more; a phenomenon which has been described as the "Matthew effect" (Merton, 1968). Lastly, according to the transmission thesis, there is a direct causality in the relationship between family and state support. Monetary resources from the state, such as pensions for the elderly, are the condition for gifts or donations from the older to the younger generations which otherwise would not be possible. In this sense, the family is a redistribution unit from the well off towards those in need, which seems to be especially effective in strong welfare states (Kohli, 1999; Kohli et al., 2000). To what extent this is the best way to allocate resources to individuals remains an open question.

Contrary to the substitution thesis and its underlying fear about the crisis of the family, the alternative approaches stress the strength of intergenerational relationships in spite of the profound changes they are undergoing. Gender is a key aspect which requires looking at how the division of work between women and men within the family is being restructured towards a more egalitarian model not only in employment, but also in care responsibilities.

Substitution is not just about family as a whole and the state. Once the social norm of mother as full-time carer belongs to the past, a diverse number of substitutes appear. Such substitutes can be provisional or permanent, full 
time or part time. Substitutes can provide care for free or for a salary and they can be relatives, friends or strangers or they can be a mix of all that. Kinship networks, and more specifically grandmothers and grandfathers, can be mother substitutes assuming a care role in their absence, and so can fathers, hired childminders or collective crèches.

A normative idea of the mother as the "normal" carer seems to underpin the concept of substitution. In this sense it is blind to current changes which are transforming the ways through which care needs are being responded to. Substitution can be looked at in a different way. Kinship support, domestic workers or nannies can be considered as state substitutes instead when childcare policies are scarce and a substantial number of families do not have access to them. In this case there is a different implicit assumption about current and future trends and about the division of responsibility between the family, its individual members and the state. Substitution is thus a double-sided concept which, on the one hand, describes how care regimes (Antonnen and Sipilä, 1996) or social care models (Daly and Lewis, 1998) are changing and, on the other hand, presupposes where the main responsibility lies.

In the following pages kinship support will be discussed as a substitute or a complement of both working mothers and social policies. Grandparents can assume full responsibility for their grandchildren when parents cannot, often due to tragic circumstances. However, this is a very specific and not unknown case, which will not be examined in this paper. In contrast, grandparents can assume care functions when the mother does exist, is there, lives with her children, often with the father, but is employed and has to make her double role as worker and carer compatible. Grandparents can substitute mothers while they are working, and take care of their small children; a form of help which could also be conceptualised as substituting social policies that are not yet or insufficiently developed to reconcile family and employment. Grandparents' role can be less intensive where they assume certain kinds of tasks as a complement to other available care resources. Kinship support as a substitute for or complement to help will be presented in a comparative perspective for three different cases: Spain, France and Norway.

\section{Three case studies}

\section{Grandparents as carers in Spain}

When asked about childcare help, one out of four Spanish working mothers answers that the main resource they can count on is their own mother (i.e. the maternal grandmother). Other members of the family network are mentioned in $10 \%$ of the cases and $25 \%$ say the husband or partner is the main provider of help. Two-thirds state that it is the nuclear or extended family which provides help, while $10 \%$ respond that the market-paid domestic help-is the main resource. State care is almost non-existent, with less than $5 \%$ receiving help of this kind. Interestingly enough, time and space strategies seem to be extremely important for working mothers. 
Table 1. Working mothers' main childcare resource

\begin{tabular}{lc}
\hline Their own mother & 26.7 \\
Husband/partner & 24.7 \\
Living near workplace & 13.9 \\
Other members of the family & 10.2 \\
Paid domestic help & 9.2 \\
Working schedules & 7.8 \\
Living near the children's school & 4.4 \\
Services offered by school & 1.5 \\
Other resources & 0.7 \\
None & 0.8 \\
\hline Total & 100 \\
\hline
\end{tabular}

Source: Survey on Spanish working mothers' strategies, ECFE 1999 (Fernández Cordón and Tobío, 2005: 31)

Two-thirds of employed mothers think kinship support is important for them, while one in five says that without such help they would not be able to work. Help provided by relatives, mostly grandparents, is also important for middle-class mothers, but for those with a low income it is often a necessary condition for them to have a job.

The kind of things grandparents do for their daughters and grandchildren is varied. In quantitative terms, the most important are non-regular tasks such as staying with their children when they get ill, at weekends and during holidays, when the person who normally takes care of them is not available, or in any other exceptional occasion. In 30\% of the cases, the maternal grandmother takes care of children under the age of three daily when they do not attend a crèche or nursery school. The maternal grandmother also cares for small children over the age of three when they come back from school, prepares meals for them or takes them to school and picks them up. Other grandparents also help out with all these tasks, but dedicate less time to them (Tobío, 2005: 162-163).

Grandparent carers do exist in many other countries (Grundy, 2007; Gesta-Anstett, 2001; Herlyn, 2001). A comparative survey of Europe shows that in other Mediterranean countries such as Greece or Italy a higher proportion of women over fifty (20\%) take care of small children daily, normally their grandchildren, compared to only $14 \%$ in Spain. In Nordic countries such as Denmark less than $5 \%$ of middle-aged women assume this task. What is specific about the Spanish case is that care work is much more intensive. Spanish dedicate the highest number of hours to care work in Europe, with 65\% of carers doing so for more than four hours per day (Eurostat, 1997). In general, all kinds of support (monetary, services or co-residence) from grandparents to adult children and grandchildren seem to be less likely but more intense in Southern European countries, particularly in Spain (Kohli, 2008).

Social policies targeted at dual-earner families or to reconcile family and employment are rather limited in Spain. A law was passed in 1999 (Ley de 
Conciliación de la Vida Familiar y Laboral de las Personas Trabajadores) to transpose European directives on maternity and paternity leaves, including reductions in the number of working hours for family purposes. The 1999 law is very generous in terms of time, permitting up to a three-year leave for parents who want to take care of their children at home and a one-year leave to take care of other relatives. However, the law is not so generous in monetary terms: leaves are unpaid, with the exception of sixteen-week maternity leaves. Only a small number of well-off families can afford losing one income, so this kind of resource is not very popular. A new law was passed in 2007 on gender equality (Ley para la Igualdad Efectiva de Mujeres y Hombres) which includes different measures to promote the involvement of mothers in paid work and of fathers in care. A new paternity leave based on the "use it or lose it" principle (i.e. paternity leaves are not transferable to the mother) has been implemented. At present, paternity leaves are two weeks long, which will progressively increase up to four weeks by 2011. As occurred previously in other countries (Leira, 2002), this measure has met with great success and enjoyed high takeup rates, with about $80 \%$ of eligible fathers taking advantage of the scheme according to the first provisional data available (El País, 2009).

Childcare services for under threes have increased considerably in the last decade, but they are still a far cry from the 33\% objective agreed by the European Union in the Lisbon Strategy for the year 2010 (Velikova, 2005). According to the most optimistic estimations, the proportion of children attending collective childcare is $25 \%$. Taking into account differences between regions, long waiting lists, and the increasing number of working mothers, the unattended demand has been estimated to be at least another $25 \%$ (Balaguer, 2004). In spite of such a deficit, Spain is no longer at the bottom of the list. Other Mediterranean countries such as Greece or Italy, as well as some Central Europe ones like Austria or Germany have not yet reached the $10 \%$ level in terms of the proportion of children in publicly monitored crèches (OECD, 2009). A majority of the Spanish population considers that the best option for small children's care is good collective services (54\%) rather than being taken care of at home (42\%) (Centro de Investigaciones Sociológicas, 2008). All children aged three and older go to school, but this does not solve all the problems. Filling in the gaps between parents' work schedules and children's school schedules is a complicated task generally assumed by grandparents when they are available. If they are not, or the family cannot afford paid help, the tension between work and care responsibilities rises dramatically, and the same applies to holidays or children's illnesses (Tobío, 2005).

The logic of kinship support is related to gender in a two-fold sense. It is the women of the family who are the main providers of care, thus explaining why grandmothers help more than grandfathers. Maternal grandmothers, for example, are the ones who take care of their grandchildren daily in $31 \%$ of the cases and, when the mother works, while maternal grandfathers only do that in $19 \%$ of the cases. Similar differences apply to all other tasks they do 
in support of their daughters. On the other hand, most of the help provided is given to daughters rather than sons or daughters-in-law. In the hierarchy of support, the indisputable first position corresponds to the maternal grandmother, but the second place is not occupied by paternal grandmothers as one might expect, but to the maternal grandfather (Tobío, 2005). The most likely key aspect to explain the intense flow of solidarity from grandparents is the rapid social change taking place in Spain. Thirty years ago female activity was low in the country and most women left the labour market when they became mothers. By the year 2008, 50.5\% of all women were active; $80.6 \%$ in the $30-34$ age group and $76.2 \%$ in the $35-39$ age group (Instituto Nacional de Estadística 2008). What is even more significant is that most of them work full time; a fact that probably explains increasing gender equality in Spanish society, but which makes intergenerational solidarity an essential resource.

Grandparents' help is independent of social class, but clearly associated to mothers' employment. For lower class mothers it is indispensable. This is how Charo, a lone mother who works in a small factory, put it:

My mother knows she is the only person I can count on. If I didn't have my mother I wouldn't be able to do anything. My mother helps me take the kids to school, gives them their lunch, picks them up in the afternoon. I wouldn't be able to work if she wasn't there because I can't afford a person to do all that while I'm working. It is my mother. If it wasn't for my mother I don't know what I would do...

For middle-class professional mothers like Sonia, a lawyer in a multinational corporation, the role of her own mother and her family network is different. They are the last resource she can count on if anything goes wrong in the well-organised domestic machinery she has set up. Her demanding job, as well as her husband's, requires anticipating any problems that might arise and having a solution. They can afford buying help, but sometimes it is not a question of money. When unexpected problems arise, she knows her mother is always there, which is extremely important for her because she knows she can rely her and does not have to worry. This is how she put it:

I have it all worked out. Imagine that the problem is that the nanny has to leave for a few days, as happened to me recently because her father who lives in a small village got ill. I ask myself, what can I do? Well, my mother is there. I know she can do that and that I can count on her when those kinds of things happen.

Grandparents' help can substitute mothers who are no longer full-time carers and who do not have other available resources, as the case of Charo exemplifies. It also complements other types of childcare help in exceptional circumstances, as Sonia's story shows. This is how social status comes into the picture. 


\section{The French patchwork of care}

France has a long tradition of family policies, which have slowly shifted from pro-natalist policies aimed at supporting the male breadwinner model during the first part of the twentieth century to new kinds of measures developed since the seventies to help working mothers reconcile family and employment (Hantrais and Letablier, 1996). Women now have the right to choose if they want to stay at home to take care of small children or go on working in their jobs, with the state helping in both cases. This is a clear difference with Spain where, for decades, family policies have not been very popular as they were associated to the Francoist dictatorship of 1939-1975 (Threlfall et al., 2004). In France, expenditure on social protection for families and children accounts for $2.5 \%$ of GDP, $2.1 \%$ above the EU-27 average. Spain, however, with just $1.1 \%$, is among the lowest (Eurostat, 2008).

Female employment has been high in France for a very long time and a majority of women $(70.8 \%)$ work full time, as in the case of Spain $(76.7 \%)$ (Eurostat, 2009). Care of small children when mothers are employed is based on three different resources, all of which are publicly financed to some extent: crèches, childminders and domestic workers. Almost a third of children under three attend the "école maternelle", as well as 100\% over that age; a proportion which clearly goes beyond the target set for 2010 under the Lisbon Strategy. Other after-school services, as well as canteens and recreational activities, have developed extensively to make the dual-earner family model viable (Fagnani, 2000, 2006). Parents can also choose childminders (assistants maternelles) who are state supported through a specific subsidy created in 1990 to this effect (AFEAMA, Aide à la famille pour l'emploi d'une assistante maternelle agréée) or have help at home to take care of their children; an option for which the state pays social security costs (AGED, Allocation de garde d'enfant à domicile). Parents may also choose to take care of their children personally. When this is the case they receive (since 1994) another type of allowance (Allocation Parentale d'Education) after having a second child. It is a flat rate compatible with part-time work until the child reaches the age of three. In 2002 a fourteen-day paternity leave was established, which has rapidly been adopted as a generalised social practice by eligible fathers (Letablier and Lanquetin, 2006).

In short, the French state provides a wide range of childcare possibilities according to families' interests and preferences. However, they are not gender neutral or class neutral (Crompton, 2006). As a number of experts have pointed out, choosing one or another option follows a certain logic which may produce or reproduce inequalities between men and women or different social groups. Low-skilled mothers living in partnership are those who generally opt for staying at home or if they work, taking the children to a crèche, whereas professionals tend to use privatised childcare in the home (Fagnani, 1998; Micheaux and Monso, 2007).

In spite of generous state policies for families with children, the role of kinship networks in childcare remains an important resource in France (Des- 
planques, 1993; Gregory and Windebank, 2000). The Three Generations Survey gives detailed information about the role of grandparents as carers (Attias-Donfut and Segalen, 1998). A majority of grandparents (82\%) regularly take care of their grandchildren; more often grandmothers $(85 \%)$ than grandfathers $(75 \%)$ and often once a week $(34 \%)$, once a month $(19 \%)$ or during holidays (25\%). Their support is not limited to children under three; it may be even more important when they go to school to fill in gaps between children's and parents schedules. Regardless of their socioeconomic origin, most grandparents help taking care of their grandchildren, but the number of hours they dedicate to it makes a difference. Care during weekdays is much more extended among lower income groups than among professionals and high-skilled workers. Kinship support is particularly intense when mothers are in a difficult economic situation or they are unemployed.

The comparison between the French and the Spanish case reveals other interesting similarities. In both cases, help is transmitted mainly through the feminine line, that is, from mothers to daughters, who are the key explanatory factor of intergenerational solidarity (Bloch and Buisson, 1996; Dench and Ogg, 2001). On the other hand, help seems to be a way of supporting mothers who remain in paid work instead of becoming full-time carers. Unlike the Spanish case, this is especially clear in the French case among low-income mothers (Attias-Donfut and Segalen, 1998). The role of grandparents increases in cases of separation or divorce; a trend that is not new (Kalmijn, 2008). Finally, living nearby in the same city, neighbourhood, street or building is clearly correlated to grandparents' support in both France and Spain. What makes a difference is that this happens much more often in Spain, as a result of an explicit strategy to live near relatives and particularly the maternal grandmother (Tobío, 2005).

In short, it can be said that in France, as in Spain, grandparents are playing a relevant role as carers of their grandchildren. Although support is provided mainly through women from grandmothers to mothers, maternal grandfathers do play a role and are often more active carers than they were as fathers. Both countries also share the fact that this kind of help relates to the massive entrance of women in the labour market and more specifically of mothers. The nuclear family is not enough when both parents are employed; the new extended family, which does not generally cohabit, is one of the resources they can count on. There are, though, important differences between the French and the Spanish case. In France, the state provides basic support for childcare in many different forms, while grandparents fill in certain gaps; especially when mothers are facing some kind of difficulty or have demanding jobs. Hence, family support complements strong state support. In Spain, intergenerational solidarity can instead be conceptualised as a substitute for the scarcity of childcare policies. Grandmothers are not just filling in gaps, but are often the full-time main carers of their grandchildren when mothers are employed. Hence, they may be seen as a provisional solution for the first generation of Spanish working mothers. 


\section{The first generation of working mothers in Norway and Spain}

In the well-known typology of welfare states defined by Esping-Andersen (1990), Norway appears as one of the social democratic cases characterised by the universal provision of social services based on an egalitarian approach to citizenship. Informal care of children, the elderly or other dependent persons in the private sphere of the family is a missing dimension in this typology as authors like Lewis (1992) or Orloff (1993) have pointed out. The Norwegian sociologist Arnlaug Leira has analysed in depth the specific characteristics of the transition to a dual-earner family model in this country, showing the relevant role which informal care played during the first stages of the involvement of mothers in paid work during the sixties $(1992,1993,1996)$. Nordic countries are not all the same, though they tend to be equated to the Swedish case. Lewis's alternative typology, which introduces care as one of the explanatory variables, takes this into account and classifies Sweden as a "weak breadwinner model" and Norway as a "modified breadwinner model".

During the post-war years from 1945 to 1960 , Norwegian female activity rates and, particularly that of mothers, were very low in the European context. At the beginning of the sixties only $5 \%$ of married mothers with small children were employed (Leira et al., 2005), but during those years women's involvement in employment increased very rapidly and by the end of the decade the dual-earner family became the norm. Working mothers had great difficulties in making their double responsibility compatible. Part-time work was scarce and public resources for childcare almost non-existent; a situation that would closely resemble that of Spanish working mothers twenty years later.

When compared today, Norway and Spain differ in many regards, but there are other ways to make comparisons. Social changes occurring in different moments at different places such as demographic transitions (Arango, 1980; Van de Kaa, 1987) or political transitions from authoritarian to democratic regimes (Almond and Verba, 1963; O'Donnell et al., 1986) can also be compared. In this case, the particular transition to look at is that between the family based on gendered roles to a new family model where both the father and the mother are in paid work. This is a historical change which is happening in all European countries and in many other parts of the world, but does not necessarily happen at the same time. More specifically, what is compared between Norway and Spain is the "first generation of working mothers", that is, the moment at which they become the new social norm, which can be quantified as $40 \%$ of all mothers of small children. Even if the data are not exactly comparable (Table 2), it can be estimated that this level was reached in Norway in the early seventies and in Spain by 1990, but in spite of the time difference (more than two decades), the way women, the family and the state interplay bears many resemblances.

In Norway, as in Spain, the involvement of women, and particularly of mothers, in the labour market is directly related to the expansion of administrative jobs and public services such as health and education. In addition, there 
Table 2. Evolution of female activity in Norway and Spain

\begin{tabular}{lc}
\hline \multicolumn{1}{c}{ Norway } & $\%$ \\
\hline 1960 (Married working mothers with children $<7)$ & $5 \%$ \\
1968 (Married women who work) & $40 \%$ \\
1985 (Working mothers with children <3) & $50 \%$ \\
\hline \multicolumn{1}{c}{ Spain } & $\%$ \\
\hline 1980 (Active women aged 30-34) & $30 \%$ \\
1990 (Active mothers with children <3) & $41 \%$ \\
2000 (Active mothers with children $<3$ ) & $54 \%$ \\
\hline
\end{tabular}

Source: Norway: Leira, 1994; Leira at al., 2005. Spain: 1980: National Institute of Statistics. Labour Force Survey. II trimester; 1990 and 2000: own data from Labour Force Survey II trimester.

is a strong feminist ideology about women's autonomy through involvement in paid work, their educational skills also grow rapidly, and families increasingly need a second income. In both countries the transition from the mother-athome family model to the dual-earner model took place very rapidly; in less than twenty years. Moreover, these changes occurred in both cases in spite of the lack of social policies to facilitate the new model. It would not be until the eighties, when a majority of mothers were already in the labour market, that policies to reconcile family and employment were widely developed in Norway thanks to strong social and political pressure from feminist organisations and from women active in politics (Ellingsaeter, 1995; Leira, 1992).

As discussed elsewhere (Leira et al., 2005), state intervention through public policies does not necessarily precede the family transition. In many cases, as those presented here, it is rather informal support networks that make such change possible. According to data from a national survey conducted in Norway from 1968 (Statistik Sentralbyra, 1969), only 11\% of children under the age of six attended a collective childcare service, whereas $40 \%$ were taken care of by childminders, grandparents, other relatives, friends or neighbours. In the other half of the cases, care was provided within the nuclear family. Parents had different work schedules; a strategy which could be combined with mothers' part-time jobs, or one of the parents worked at home, especially in certain occupations like agriculture or small shops.

As in Spain during the transition to a dual-earner family model, kinship support also played a role in Norway. One in ten children was taken care of by grandparents, which were one more resource among other informal solutions. However, the logic of informal support differs in both countries. Relatives, including grandparents, seem to be more distant in Norway. For example, they could receive money for their help, something that does not happen in Spain. On the other hand, childminders, who were paid, had a certain quasi familiar status which blurred differences between informal family carers and non-family carers (Leira et al., 2005).

The social-democratic welfare state model was set up in Norway in the eighties. This model is based on a combination of parental leaves of up to 
fifty-two weeks with $80 \%$ wage compensation and public childcare for small children before they go to school. At the time more than one-third of all preschool children attended collective crèches and those who did not received a cash benefit (Leira et al., 2005).

\section{Grandparents, a substitute or complementary resource for childcare?}

Contrary to the idea that modernisation meant the decline of intergenerational relationships beyond the nuclear family, a new kind of extended family seems to have developed in different countries, playing an important role in the care of small children. This new extended family is related to mothers' involvement in paid work, which is actively supported by female relatives and particularly by maternal grandmothers. Kinship support takes different forms, is more or less intense, and has different meanings according to the development of social polices, and also to the kind of norms and expectations concerning the nuclear family.

In Spain, the role of grandparents is both a substitute and a complement of other resources. Often, grandparents are full-time carers of their small grandchildren; an intense dedication that can be conceptualised as a substitution of mothers at work who, if it were not for that reason, would be taking care of their children at home. This is one way to look at it, but not the only one. Informal support, including kinship, as the Norwegian case shows, may be a provisional solution for a transitional period. The new family model based on two earners requires that care be organised in a new manner; while this does not take place, as in Spain today, all resources are welcome. The structural situation in Spain in 2000 and in Norway in the sixties bear a large resemblance: mothers are rapidly entering the labour market for a variety of reasons, but the social organisation remains very much the same. State intervention has not preceded the "adult worker model" (Lewis, 2007), but rather mothers themselves and their families have to develop private and informal strategies to make the dual-earner model viable. What differs is the kind of available informal resources. In Norway there was a varied number of ways of caring for children; some based on the nuclear family, others on the extended family or the community, such as friends, neighbours or childminders. In Spain, the main resource lies in the extended family and particularly in the intense mother-daughter relationship. This difference could be explained by the role of the nuclear family, the family network and the community in both countries. In Spain, and to some extent in France, the main dividing line between these three social institutions lies between family and non-family members. There is a strong vertical line based on parent-child relationships which structures kinship support beyond the nuclear family (Fernández Cordón and Tobío, 2007). The rest, the community, is on the outside, and is not normally expected or asked for help in issues like childcare. In Norway, the main dividing line probably lies between the nuclear family and the outside, with more tenuous differences between relatives and members of the community. This might explain 
Figure 1. Borders between nuclear family, family network and community in Spain and France

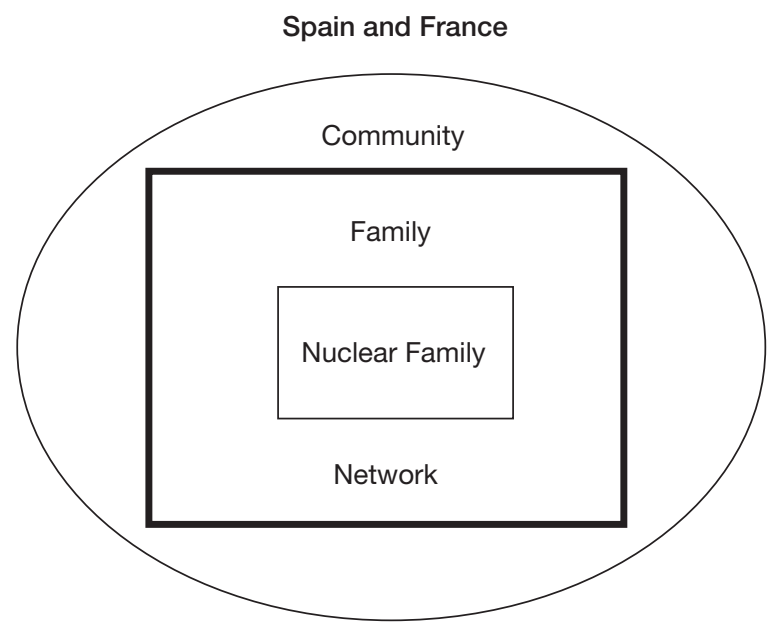

Figure 2. Borders between nuclear family, family network and community in Norway

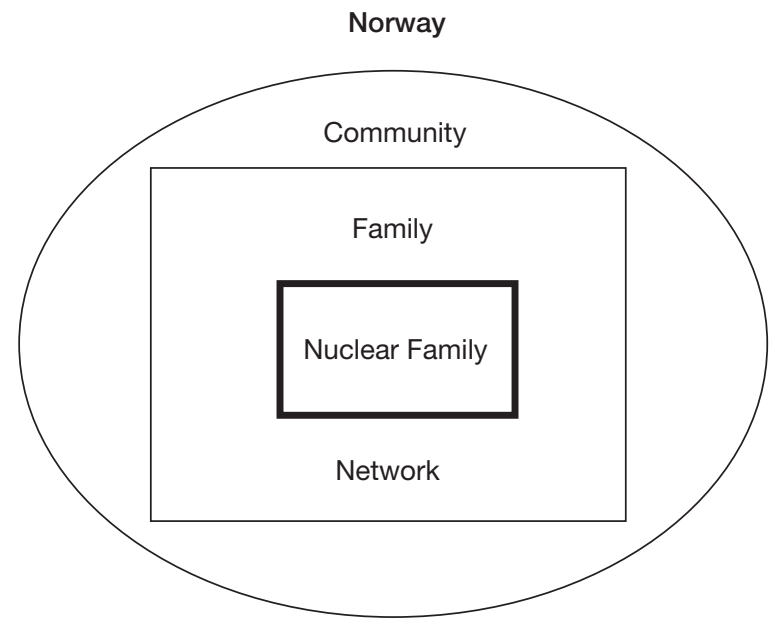

why grandparents were just one more informal resource among others during the transitional period before a new social organisation of care appeared.

Grandparents as care substitutes go beyond intergenerational reciprocity. In the logic of what each generation gives and receives, it is for parents, specifically mothers, to assume the responsibility of their children. As women enter paid work, care needs to be organised differently. While this happens, grandparents 
play a key role in making the new family model possible, which is also a new economic model. If mothers and fathers work full time, grandparents also provide care full time as is the case in Spain still today, and they do so even when there are doubts about how they themselves will be taken care of in the future when they will need it. They can see that their daughters, whom they are helping now, are not available for full-time care because they are working mothers, and they become aware of the fact that new forms of care will also have to be developed for the elderly. Thus the help they provide is not in exchange for what they have received from the former generations or for what they expect to receive in the future. It is pure solidarity; they do it because they can and because their daughters, or sons, and grandchildren need it. Yet this does not mean that parents are "crowded out"; they go on assuming the main responsibility for their children in all senses with the exception of direct care while they are at work.

Social class does make a difference. Among middle-class working mothers, grandmothers are not usually full-time carers of their grandchildren, but they do play a role in coordinating or controlling childminders, taking the children to school, or as a last resource in the event that the other arrangements are not available. In this sense, kinship support plays a complementary role in Spain when other resources are affordable.

Grandparents in France are normally a complementary resource. In spite of generous and varied childcare policies from among which families may choose, grandparents assume some specific tasks related to their grandchildren. Often they do such tasks on a regular basis (once a week or once a month), but only for a small number of hours. They fill in the gaps which are not fully covered by other resources, thus supporting their daughters' employment, which is usually full time. Grandparents are the earmarked available resource; those on which mothers and their families can count on when necessary. Moreover, it is likely that they are so because of the implicit assumptions regarding exchange relationships between the nuclear family and the extended family. This is very similar to the Spanish case when full-time help is not necessary either because children are already at school, parents' working schedules are well coordinated with children's schedules or there are other carers who assume the daily work. Social class can make a difference in France, especially among immigrants when there is a preference for family care or access to others forms of childcare is not available or affordable. In these cases grandparents can also be full-time carers.

In short, grandparents play a key role when mothers' employment becomes the norm, not just in the Southern European countries like Spain. In this sense, kinship support for childcare is an extraordinary resource in moments of social change such as the transition to a dual-earner family model. It does not relate to the past but rather to the future. Grandparents can also be an ordinary resource which complements social policy, as in France. How the Spanish case will develop in the future is still an open question, but there are indicators of the unwillingness of grandparents to continue providing intensive 
care for different reasons (excessive workload for people who are no longer young, advantages of early socialisation for the children, rejection of traditional values transmitted by grandparents, among others). Furthermore, there are ambitious governmental social policy projects to extensively develop collective childcare (PSOE, 2008) that have been implemented in part as recent data on the increase in childcare services for under threes show. Over the last five years (2005-2010), the number of children under the age of three attending registered childcare facilities has doubled, now reaching 400,000 (Ministerio de Educación 2011). If this trend continues, kinship support might go on being an important complement for care, but only as one more piece in the new patchwork quilt. On the other hand, however, the effects of the current economic crisis on mothers' employment might continue making the help of grandparents a necessary resource.

\section{Bibliographic references}

Almond, Gabriel A. and Verba, Sidney (1963). The Civic Culture, Princeton. New Jersey: Princeton University Press.

AntonuCCI, Toni C. and Jackson, S. James (1990). «The role of reciprocity in social support». In: Sarason, Barbara R.; Sarason, Irwin G. and Pierce, Gregory P. (eds.). Social Support: An Interactional View. New York: Wiley, 173-198.

Antonnen, Anneli and Sipilë, Jorma (1996). «European social care services: is it possible to identify models». Journal of European Social Policy, 6, 2, 87-100.

Arango, Joaquín (1980). «La teoría de la transición demográfica y al experiencia histórica». Revista Española de Investigaciones Sociológicas, 10, 169-198.

Attias-Donfut, Claudine (ed.) (1995). Les solidarités entre générations. Vieillesse, Familles, État. Paris: Nathan.

Attias-Donfut, Claudine and Segalen, Martine (1998). Grands-Parents. La famille a travers les générations. Paris : Odile Jacob.

BALAgUeR, Irene (2004). Situación de la oferta de servicios existente para menores de tres años durante la jornada laboral de sus padres. Madrid: Ministerio de Trabajo y Asuntos Sociales.

BALBO, Laura (1987). «Crazy quilts: rethinking the welfare state debate from a woman's point of view». In: SHOwstack Sassoon, Anne. Women and the State. London: Hutchinson.

BeCKER, Henk (2000). «Discontinuous change and generational contracts». In: Arber, Sara and Attias-Donfut, Claudine. The Myth of Generational Conflict. The family and state in ageing societies. London and New York: Routledge/ESA Studies in European Societies, 114-132.

BLOCH, Françoise and Buisson, Monique (1996). Faire garder ou garder les enfants: une affaire de femmes. Paris: Ministère du Logement, Direction de l'Habitat et de la Construction.

Bonvalet, Catherine and OGG, Jim (eds.) (2007). Measuring Family Support. UK: INED/Southern University Press.

Bourgeors, Léon (1998 [1896]). Solidarité. Villeneuve d'Ascq: Presses du Septentrion.

Castles, Francis G. and Obinger, Herbert. (2008). «Worlds, families, regimes: Country clusters in European and OCDE area». West European Politics, 31, 1-2, 321-344. 
Centro de Investigaciones Sociológicas (2008). «Estudio no 2766». Centro de Investigaciones Sociológicas: Madrid.

Crompton, Rosemary (2006). Employment and the family: the reconfiguration of work and family life in contemporary societies. Cambridge, UK and New York: Cambridge University Press.

DALY, Mary and LEWIS, Jane (1998). «Introduction: conceptualising social care in the context of welfare state restructuring». In: Lewis, Jane. (ed.). Gender, Social Care and Welfare State Restructuring in Europe. Aldershot: Ashgate, 1-24.

Dench, Geoff and OGG, Jim (2001). «Grands-parents par la fille, grands-parents par le fils». In: Attias-Donfut, Claudine and Segalen, Martine. Le siécle des grandsparents. Une génération phare, ici et ailleurs. Paris : Autrement, 187-199.

Desplanques, Guy (1993). "Garder les petits : organisation collective ou solidarité familiale». La Societé Française, 293, 330-338.

Durkheim, Émile (1956 [1893]). The Division of Labour in Society. New York: The Free Press.

El País (2009). «El Congreso aprueba las cuatro semanas de permiso de paternidad». Madrid: 19 June, 45.

Ellingsaeter, Annelise L. (1995). Gender, Work and Social Change. Oslo: Institute for Social Research.

Esping-Andersen, Gosta (1990). The Three worlds of Welfare Capitalism. Princeton: Princeton University Press.

- (1999). Social Foundations of Postindustrial Economies. Oxford: Oxford University Press.

Eurostat (1997). «Les responsabilités familiales- comment sont- elles partagées dans les ménages européens». Statistiques en bref. Population et conditions sociales, 5, 5-7.

- (2008). «Social Protection in the European Union». Statistics in Focus, 46.

- (2009). «Labour market: latest trends». Statistics in Focus, 14.

Fagnani, Jeanne (1998). «Helping Mothers to Combine Paid and Unpaid Work- or Fighting Unemployment? The Ambiguities of French Family Policy?». Community, Work and Family, 1, 3, 297-312.

- (2000). Un travail et des enfants. Petits arbitrages et grands dilemmes. Paris: Bayard.

- (2006). «Family Policy in France». In: FitzPatrick, Tony; Kwon, Huck-ju, ManNING, Nick; Midgley, James and Pascall, Gillian. International Encyclopedia of social Policy. London: Routledge.

Fernández Cordón, Juan Antonio and Tobío, Constanza (2005). Conciliar las responsabilidades familiares y laborales: politicas y prácticas sociales. Madrid: Fundación Alternativas.

- (2007). Andalucía. Dependencia y solidaridad en las redes familiares. Sevilla: Instituto de Estadística de Andalucía.

FInCH, Janet and Mason, Jennifer (1993). Negotiating Family Responsibilities. London: Routledge.

Garfinkel, Harold (1984). Studies in Ethnomethodology. Cambridge: Polity Press.

Gessat-Anstett, Elisabet (2001). "Les babouchki, des femmes qui durent». In: Attias-Donfut, Claudine and Segalen, Martine. Le siécle des grands-parents. Une génération phare, ici et ailleurs. Paris : Autrement, 127-141.

Gide, Charles (1893). "L'idée de solidarité en tant que programme économique». Revue internationale de sociologie, october (cited by Paugam, Sérge. (ed.) (2007) Repenser la solidarité. L'Apport des sciences sociales, París: Presses Universitaires de France, p. 27). 
Gouldner, Alvin W. (1960). «The norm of reciprocity: a preliminary statement». American Sociological Review, 86, 1019-1028.

Gregory, Abigail and Windebank, Jan (2000). Women's work in Britain and France. Practice, Theory and Policy. London: Macmillan Press.

Grundy, Emily (2007). «Intergenerational Exchanges in Older Populations». In: Véron, Jacques; Pennec, Sophie and Legaré, Jacques (eds.). Ages, Generations and the Social Contract. The Demographic Challenges Facing the Welfare State. Dordrecht: Springer, 209-230.

Hansen, Karen V. (2005). Not-so-nuclear families. Class, gender, and networks of care. New Brunswick, New Jersey and London: Rutgers University Press.

Hantrais, Linda and Letablier, Marie Thrérèse (1996). Families and Family Policies in Europe. London and New York: Longman.

Herlyn, Ingrid (2001). «D’Est en Ouest, les styles des grands-mères allemandes». In: Attias-Donfut, Claudine and Segalen, Martine. Le siècle des grands-parents. Une génération phare, ici et ailleurs. Paris : Autrement, 116-126.

Instituto Nacional de Estadística (2008). Encuesta de Población Activa, Madrid (www.ine.es).

Kalmijn, Matthijs (2008). "The effects of separation and divorce on parent-child relationships in ten European countries». In: SARACENo, Chiara (ed.). Families, Ageing and social Policy. Intergenerational Solidarity in European Welfare States. Cheltenham, UK and Northampton, MA, USA: Edward Elgar, 170-193.

KnIJN, Trudie (2004). «Family Solidarity and Social Solidarity: Substitutes or Complements?». In: Knijn, Trudie and KomTer, Aafke (eds.). Solidarity Between the Sexes and the Generations, Transformations in Europe. Cheltenham, UK and Northampton, MA, USA: Edward Elgar, 18-33.

KoHLI, Martin (1999). «Private and public transfers between generations. Linking the family and the state». European Societies, 1, 1, 81-104.

Kohl, Martin; Künemund, Harald.; Motel, Andreas and Szydlik, Marc (2000). «Families apart? Intergenerational transfers in East and West Germany». In: Arber, Sara and Attias-Donfut, Claudine. The Myth of Generational Conflict. The family and state in ageing societies, London and New York: Routledge/ESA Studies in European Societies, 88-99.

Kohli, Martin and Albertini, Marco (2008). «The family as a source of support for adult children's own family projects: European varieties». In: SARACENO, Chiara (ed.). Families, Ageing and Social Policy. Intergenerational Solidarity in European Welfare States. Cheltenham, UK and Northampton, MA, USA: Edward Elgar, 38-58.

Künemund, Harald (2008). «Intergenerational relations within the family and the state». In: Saraceno, Chiara (ed.). Families, Ageing and social Policy. Intergenerational Solidarity in European Welfare States. Cheltenham, UK and Northampton, MA, USA: Edward Elgar, 105-122.

LeIrA, Arnlaug (1992). Welfare States and Working Mothers: the Scandinavian Experience. Cambridge: Cambridge University Press.

- (1993). "The Woman Friendly Welfare State? The case of Norway and Sweden». In: Lewis, Jane (ed.). Women and Social Policies in Europe. Aldershot: Edward Elgar.

- (1994). "Combining work and family: Working mothers in Scandinavia and the EC». In: Brown, Philip and Crompton, Rosemary (eds.). A New Europe: Economic Restructuring and Social Change, London: UCL Press, 86-107. 
Leira, Arnlaug (1996). Parents, children and the state: Family obligations in Norway. Oslo: Institutt for samfunnsforskning.

- (2002). Working Parents and the Welfare State. Family Change and Policy Reform in Scandinavia. Cambridge: Cambridge University Press.

Leira, Arnlaug; Tobío, Constanza and Trifiletti, Rossana (2005). «Kinship and informal support: Care resources for the first generation of working mothers in Norway, Italy and Spain». In: Gerhard, Ute; Knijn, Trudie and Weckwert, Anja. Working Mothers in Europe. A Comparison of Policies and Practices. Cheltenham UK and Northampton MA USA: Edward Elgar, 74-97.

LEITNER, Sigrid (2003). "Varieties of familialism. The caring function of the family in comparative perspective». European Societies, 5,4, 353-375.

Letablier, Marie Thérèse and LAnquetin, Marie Thérèse (2006). "Concilier travail et famille en France: approches socio-juridiques». Research Paper, Paris: Centre d'Etudes de l'Emploi.

LEWIS, Jane (1992). "Gender and the development of gender regimes», Journal of European Social Policy, 3: 159-173.

LEWIs, Jane (ed.) (2007). Children, changing families and welfare states. Cheltenham UK and Northampton MA, USA: Edward Elgar.

Mauss, Marcel (2000 [1950]). The gift: the reason for exchange in archaic societies. London: Routledge.

Merton, Robert K. (1968). Social Theory and Social Structure. New York: Free Press.

Micheaux, Sandrine and Monso, Olivier (2007). «Faire garder ses enfants pendant son temps de travail». INSEE Premier, 1132 (http://www.insee.fr/fr/ffc/ipweb/ ip1132/ip1132.pdf.)

Ministerio de Educación (2011). Datos y cifras. Curso escolar 2010-2011, Madrid.

Moreno, Luis (2000). Ciudadanos precarious. La "última red" de protección social, Barcelona: Ariel.

O’Donnell, Guillermo; Schmitter, Philippe C. and Whitehead, Laurence (eds.) (1986). Transitions from Authoritarian Rule. Baltimore and London: The John Hopkins University.

OECD (2009). Society at a glance, (www.oecd.org/els/social/indicators/SAG)

Orloff, Ann Shola (1993). "Gender and the Social Rights of Citizenship». American Sociological Review, 58, 3, 501-518.

Ostner, Ilona (2004). «What are children for?': Reciprocity and Solidarity between Parents and Children». In: Knijn, Trudiie and Komter, Aafke. Solidarity Between the Sexes and the Generations. Transformations in Europe. Cheltenham, UK and Northampton, MA, USA: Edward Elgar, 167-184.

PAHL, Ray E. (1984). «The restructuring of capital, the local political economy and household work strategies: All forms of work in context». In: Gregory, Derek and URrY, John (eds.). Social Relations and Spatial Structures. London: Macmillan.

Parsons, Talcott and Bales, Robert F. (2003 [1956]). Family Socialization And Interaction Process. New York: Routledge.

Paugam, Sérge (ed.) (2007). Repenser la solidarité. L'Apport des sciences sociales. París: Presses Universitaires de France.

Popenoe, David (1996). Life without father. London: Family Policy Centre.

PSOE (2008). Programa Electoral. Madrid: Comité Electoral.

Rainwater, Lee; Rein, Martin and Schwartz, Joseph (1989). Income Packaging in the Welfare State: A Comparative Study of Family Income. Oxford: Oxford University Press. 
Silverstein, Merril; Conroy, Simon J.; Wang, Haitao; Giarrusso, Roseann and Bengtson, Vern L. (2002). «Reciprocity in Parent-Child Relations Over the Adult Life Course». The Journal of Gerontology, 57B, 1, 3-13.

Simmons, Leo W. (1970[1945]. The role of elders in primitive societies. New Haven: Yale University Press.

Statistik Sentralbyra (1969). Onskerom og behov for sysselsetting blant gifte kvinner. Oslo: Statistik Sentralbyra.

Threlfall, Monica; Cousins, Christine and Valiente, Celia (2004). Gendering Spanish Democracy. London: Routledge.

Toвío, Constanza (2005). Madres que trabajan. Dilemas y estrategias, Madrid: Cátedra.

- (2008). «Redes familiares, género y política social en España y Francia». Política y Sociedad, 49, 89-106.

Ungerson, Claire (ed.) (1990). Gender and Caring: Work and Welfare in Britain and Scandinavia. New York: Harvester Wheatsheaf.

VAn de KaA, Dirk (1987). "Europe's second demographic transition». Population Bulletin, 42, 1, 2-57.

Velikova, Dessislava (2005). Lisbon Strategy. Mid-term Review from a Gender Perspective. Brussels: European Parliament, Directorate General for Internal Policies.

Véron, Jacques; Pennec, Sophie and Légaré, Jacques (eds.). Ages, Generations and the Social Contract. The Demographic Challenges facing the Welfare State. Dordrecht: Springer. 


\section{REVISTA ESPAÑOLA DE SOCIOLOGÍA}
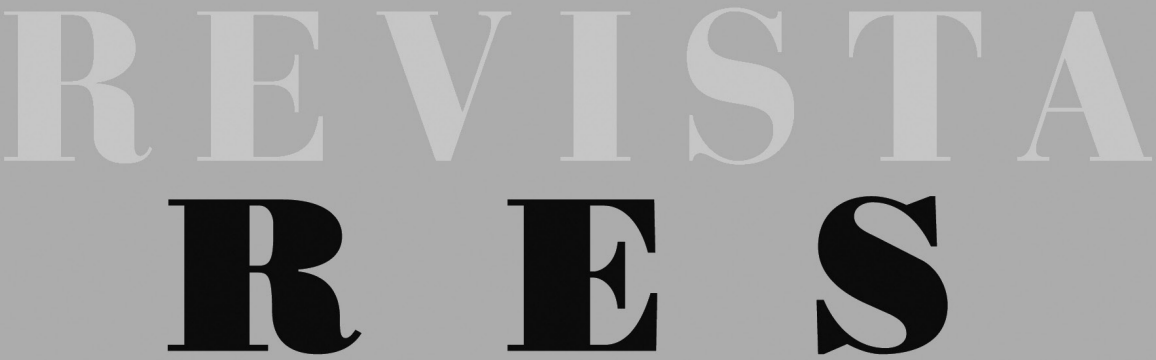

$N^{o} 17$ Primer semestre 2012
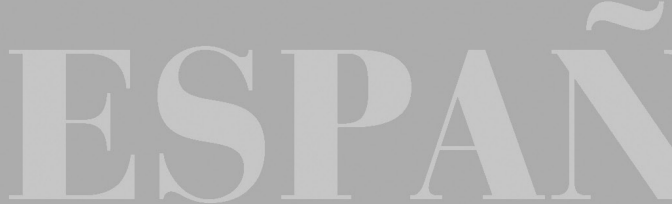

Sobre hermenéutica: de la filosofia a la sociología empírica, por Miguel Beltrán Villalva.—Los modelos de irreductibilidad social en la teoría sistémica de Niklas Luhmann, por Sergio Pignuoli Ocampo.-Motivaciones y orientaciones de los nuevos pobladores en áreas rurales alejadas, por José Antonio Pérez Rubio y Marcelo Sánchez-Oro Sánchez.- Debate: Inmigración, diversidad étnica y capital social, por Miguel Caínzos, Alejandro Portes, Erik Vickstrom, Enrique Martín Criado, Berta Álvarez-Miranda, Alfonso Echazarra, Laura Morales, Francisco Herreros, Amparo González Ferrer y Mao-Mei Liu.
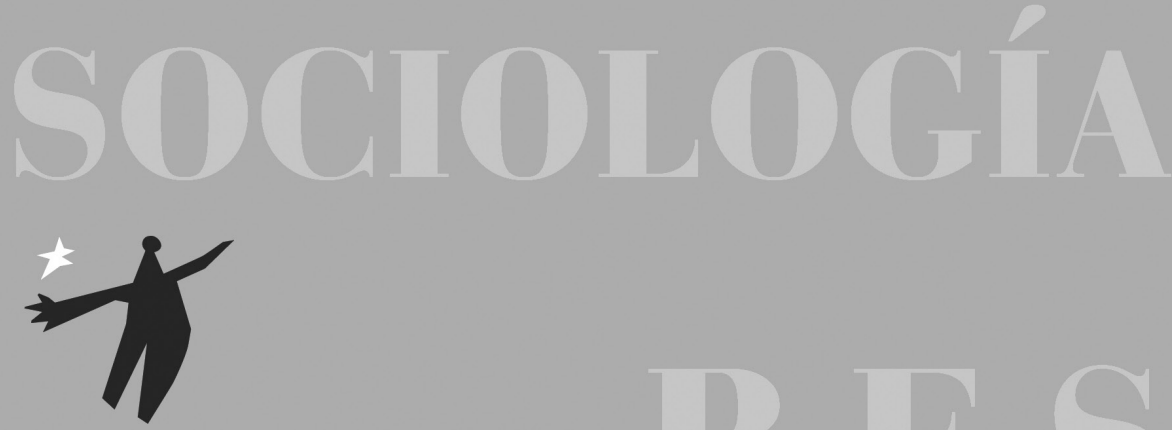

Federación Española de Sociología 